\title{
THE IMPORTANCE OF SCHOOL GOVERNING BODIES IN THE EFFECTIVE GOVERNANCE OF THE PUBLIC SCHOOLS: DO WOMEN HAVE A ROLE?
}

\author{
Lebogang M. Kekana ${ }^{1}$, Alfred H. Makura ${ }^{2^{*}}$ \\ ${ }^{1} \mathrm{Ms}$, Central University of Technology, South Africa, Ikekana@cut.ac.za \\ ${ }^{2}$ Prof., Central University of Technology, South Africa, amakura@cut.ac.za \\ *Corresponding Author
}

\begin{abstract}
This paper seeks to offer insights into the importance of school governing bodies (SGB) in the effective governance of public schools. The intention is to look in-depth, how SGBs are effective in school governance and professional management of the public schools as enshrined by the South African Schools' Act of 1996 (SASA). The paper further interrogates the role of women in school governance given that leadership and management are associated with the masculine gender. The paper adopted a desktop approach. Selected studies were used to ventilate how women are projected in the school governance matrix. Gender stereotypes of the apartheid era in South Africa have been implanted in the mind-set of many women and men. These distress their leadership performance in school circles. The paper submits that the school policies exemplified by the Constitution of South Africa and SASA offer appropriate guidance regarding how public entities such as the SGBs must execute their duties within the society. However, it is our contention that the role of women in the school management milieu is insignificant. The paper suggests ongoing capacity development workshops and training as vital in keeping up with the evolution of the education system. Women should be able to understand their roles and functions within the school and education system to make them more visible and efficient in any role. A collaborative approach (women's strength) advocates the importance of working particularly, alongside the school principals and to understand the principal's role in the SGB. Such approach shall enhance SGB's effectiveness and broaden women participation in school governance especially in South Africa.
\end{abstract}

Keywords: School Governing Bodies (SGB), women, South African Schools' Act, Governance, public schools, management

\section{INTRODUCTION}

This paper offers insights into the importance of school governing bodies (SGBs) in the effective governance of the public schools and analysing the role women play in the especially in the SGBs. The South African Schools Act (SASA) of 1996 provides for the establishment of school governing bodies (SGBs), consisting of parents, guardians of learners, educators, learners, community leaders and school principals. It is mandatory that parents of learners in that school constitute the majority of the SGB. The SGB has been tasked with steering fundamental issues, such as discipline, recruitment and promotion of teaching and non - teaching staff in a very prominent place of authority. SGBs also enforce the school language policy and budget. School governance is a feature of school leadership in schools nationwide. Although there are significant differences regarding how school governance is described, some would argue that, within the context of 
South Africa, school governance is linked, inter alia, to one of the processes and structures by which a school operates (Mafora, 2012; Joubert, 2008; Lewis \& Naidoo, 2006). Parents, educators, learners, members of the community and the school principal are an integral component of governance. School management is acknowledged as a partnership which strives for effective governance.

\section{THE SOUTH AFRICAN EDUCATION CONTEXT}

\subsection{Historical Context}

The emergence and implementation of post-apartheid school governing bodies in South African public schools stemmed from a lack of commitment to community history, particularly historically black communities in educational affairs by the apartheid government (Heystek, 2011; Mncube, 2008). The new dispensation saw it necessary to establish mechanisms that would promote active community involvement at school level. Hence, the SGB structures were instituted in all South African public schools as the first constitutional bodies to be legally recognised and directly elected by the school parents (Gamede, 2016; Heystek, 2011; Mncube, 2008). The top priority of the South African government was to implement capacity-building programs that would equip the SGBs to be effective. These initiatives can be viewed as a tool for promoting a vibrant teaching and learning environment and strong administrative and governance systems in public schools.

Changes in South Africa after attaining democracy ushered an education system based on basic principles of non-discrimination, democracy, fairness and justice (Heystek, 2011). The main factor in this change was the commitment of the South African government to an equitable education system that would optimize the participation of all stakeholders with an interest in the democratic governance of schools. The goal was to provide an opportunity for all key role players in schools to participate in management and governance of the school in order to create a healthier environment for teaching and learning. The new governance framework was based on accountability (Mpungose \& Ngwenya, 2017). This tenet was considered fundamental in the process of enhancing school governance by sharing the highly contested power without losing it. Parents and community members' participation in the SGBs may be linked to the past struggle against apartheid, which also included a few carefully chosen parents in educational matters.

\subsubsection{Legal Framework}

The representation of the SGB in a public school involves the appointed parents of the children in school; the principal serving at the school; the educators at the school; the learners at the school and those in grade 8 and above, as well as the members of the co-opted community. Section 30 of the South African Schools Act (RSA, 1996), empowers the governing body to elect the required sitting members as representatives: the chairperson, the treasurer and the secretary. According to the Section 29 of the South African School Act (SASA 1996), the chairperson of the SGB in a particular school must not be employed there. Section 30 of the SASA sets expectations on the duties to be performed by the SGB regarding the establishment of an Executive Committee and the terms of office of the members. A governing body may constitute committees, including an executive committee, in accordance with the above Act; appoint persons to such committees who are not the members of the governing body on the basis of their expertise, but each committee must be chaired by a member of the governing body. Parents in South African SGBs are mandated by law to make up the majority of SGBs, with the SGB chair being a parent (Gamede, 2016; Mncube, 2007). It was an effort to give parents power and voice to promote democratic and social justice concerns in a world riddled with racism, inequality and authoritarianism. As regards the participation of learners in the SGBs, the SASA requires that secondary school learners who are members of the Representative Council for Learners (RCL) to be part of the school governance authority by way of its presence in SGBs. Section 31 of the South African School's Act sets the term of office of members of the regulatory body other than the learners at a maximum three years. The term of office of a governing body-bearer in office cannot exceed one year. A member or office-bearer of the governing body may be re-elected or co-opted after the expiry of their term of office. The purpose of such legislation is that democratic and social problems or justice should be considered and that this is also a way to enhance the efficiency of schools (Marshall, 2004, Mncube \& Du Plessis, 2011 \& RSA Constitution, 1996).

\subsubsection{Role of SGBs in Effective Public School Governance}

The South African Schools Act (SASA) 84 of 1996 which became operational in early 1997, required that all public state schools in South Africa have constitutionally elected SGBs composed of teachers, non-academic staff, parents and learners in the case the case of secondary schools. Mncube (2007) avers that although SGBs were only legislated in South Africa in 1996 and operationalised in 1997, they already existed in England and Wales. Their primary role was the overall management of schools on behalf of local educational 
authorities, believing that SGBs could better handle and be more accountable than the latter (Farrell \& Law 1999; Mncube \& Du Plessis, 2011). To be effective, the school governing body should ensure that it endorses the best interests of the school by ensuring its success by providing quality education to all learners in the school. The SGB adopts a constitution, creates mission statement for the school and adopts a code of ethics for students at the school. It also enables the principal, educators and other staff at the school to fulfil their professional duties. The main aim of changes in governance was schooling democratisation. The White Paper on Education 2 clearly notes that governance strategy for public schools is focused on core principles of democracy (Department of Education, 1996). These core values include, encouraging representation of all stakeholders in the education system especially parents of learners within the school.

Active participation of the parents and the inclusion of women in governance roles are critical. The values of tolerance and ability to work within a group and reaching consensus are values that ensure school success. In the SGB, rationale discussions are valued as they cultivate rational thinking which ensure productive collective decision making. For instance, in the South African education context, school safety and security in public schools are paramount (Prinsloo, 2005). They are among the most complex and critical functions that most SGBs grapple with. Hence, SGBs are responsible for maintaining a physically protected environment, such as a solid school wall, restricted access and solid windows and doors. So, it is the SASA that gives effect to the functions of the SGBs. These include, among others, the determination of the language policy, school fees and the recommendation of the appointment of educators and non-educators (SASA 1996). Employee selection considers the need to address historical injustices and the need for representativeness (RSA Constitution 1996: section 20). The significance of these obligations is that members of SGBs, including parents and learners, should be well informed about school governance issues and the constitutional criteria set out in SASA. Regrettably, most SGBs are functionally weak since parental involvement is low (Gamede, 2016; Modisaotsile, 2012; Mncube, 2009). A study by Mncube (2010) reported that women were more comfortable with private than public involvement in education matters. Hence, their role and presence in SGBs is minimal.

\section{THE GENDER MATRIX IN SCHOOL GOVERNANCE}

Global education reforms in school governance emphasized a culture of governance which promotes gender inclusion (Popkewitz, \& Lindblad, 2000; Verger,. Novelli, \& Altinyelken, 2012). The apartheid era education system in South Africa implanted segregated notions in the mind-set of role players. Gender stereotypes regarding the visibility and role of many women and men in school leadership and their performance therein has been reported in several studies (Heilman, 2001, Kidder, 2002 \& Stelter, 2002). Mcpherson's (2001) findings of the Education 2000 plus longitudinal study of 27 schools across South Africa shows gradual improvements to governing bodies' race and gender profiles. While overall governing body members tend to be overwhelmingly male for all defined constituencies, there has been a small increase in female representation over the century. This could be because of historical or cultural beliefs which needs to be transformed in the current years we live in (Greif, 1994; Sewell Jr, 2005). In the 1997 South African elections at racially integrated schools, the ethnicity of elected parents appeared to align with the school's historical racial character. Where Africans and other races were included in regulatory bodies, the pattern was that they would be co-opted or included in smaller sub-committees whereas decision-making bodies were held by the executive bodies. The same pattern of racial homogeneity was noted among representatives of learners from those schools with integrated learner populations (McPherson, 2001). A later school visit in late 2001 McPherson showed a minor tendency towards racial disparity in some governing bodies of some schools. In specific schools, it was evident that the principal dominates in the SGB especially in rural areas. Following principals were educators as second highest decisions makers leaving parents to be less voiceless. As one respondent said: 'Teachers are seen by the community as educators who are knowledgeable about school issues' (McPherson, 2001). This might not always be the case in schools in the suburbs where parents are members frequently working in highly professional and managerial positions and can wield tremendous power and control in meetings. There are few such schools.

A research study by Denmark and Digorry (1966) shows that, on average, men are more dominant than women in the exercise of authority and power. Women along with males are influenced by social and cultural expectations to follow behavioural habits in accordance with the standards of society regarding how they should behave. Most cultures attribute dominant, aggressive characteristics to men and passive, dependent qualities to women. In South Africa, several women are seen outside the school yards selling foods or snacks to learners (Karlson,2002; Mncube,2007). A study by Mncube, (2007) reported that the SGB chairperson of Newtown Secondary School highlighted that women in the SGB tends to leave maximum decision powers to men in the thinking that men shall make more decisive and comprehensive decisions. In some situations, it is a norm for men to go big cities to seek better employment and leave women at home. 
Historically, women remain to raise a family and fend for the children. During school elections in such areas, women would make up majority of the SGB members as elected representatives of the SGB constituencies. Non-educator members are often the lay members of society. Hence McPherson's (2001) contention that social class education indices encoded in administrative skills seemed to transcend the patterns of gender and race in some community school settings. Women in such communities are the stewards of knowledge, particularly indigenous knowledge, since their community school systems educate the children.

Women also have the task of child-raising in traditional African culture while the men are there to maintain discipline (Seleti \& Tihompho 2014). These gender roles tend to cascade into the schools' milieu. A critical key factor regarding SGB membership appears to be marital status (Adesokan \& Makura, 2020; Chabaya, Rembe, \& Wadesango, 2009). Unmarried people tend to be marginalised and thus feel isolated in the decision-making activities (Chabaya, Rembe, \& Wadesango, 2009). Women who are single parents will pull remarks such as "I am not married therefore some school issues are not of my concern and my parents are more active in these things, it is socially expected" (Duku \& Salami, 2017). The study by Duku \& Salami (2017) stated that only married women were elected and that married women were usually considered to be "trustworthy, polite and respected" members of the community at the meetings. Once again, being married gives SGB members an additional insight and advantage in child-nurturing behaviours and family home management that is seen as the social core of society. Although women may be elected to the SGB membership, it would be in positions such as secretary, deputies of portfolios (deputy chairperson) and treasurer (Duku \& Salami, 2017). This is because, in the patriarchal inclined African cultural practices women do not have much a voice while men have more power to engage in decision-making. In some African cultures some women are expected to be submissive ostensibly as a sign of respect. Karlsson (2002) emphasizes that having more open engagements that look beyond gender natures in South African traditions, will assist to empower more women to voice out in structures such as the SGB. In this way, the SGB shall portray inclusion and democracy that will encourage more women involvement, making them more responsible in effective school governance. From their observations and views regarding the inclusion of women in the SGB, Mabasa and Themane (2002), agree that it is vital to include women in school governance. This may be due to the awareness process about the role that women can play in public schools and entire societies. Their observation revealed that men strategically dominated SGB proceedings while the women would be passively seated and listening during such meetings. Chaka (2006) opines that women in SGBs are usually side-lined by their male counterpart which leaves them feeling intimidated hence participate less effectively in the school governance issues.

\section{CONCLUSION}

This paper explained the importance of school governing bodies (SGB) in the effective governance of South Africa's public schools. It narrated how SGBs were effective in school governance and professional management of the public schools as enshrined by the South African Schools' Act of 1996 (SASA) and the Constitution. The paper briefly outlined the role of women in school governance given that leadership and management are associated with the masculine gender. Thus, South Africa's school governance reform was a crucial mechanism for the democratisation governance. The school governance regulations in postapartheid South Africa introduced a transformative reform that addressed the various social conditions while democratising school culture. Regrettably, women participation in SGB activities is hindered because of cultural norms of gender and the other societal factors. We suggest that SGBs should create adequate nonexclusionary strategies and space for discussions with parents. Meetings should use a non-exclusive language platform that encourages women parents to feel unmarginalised by creating spaces for dialogues and discussions. SGBs are a new model with democracy but with less interference from parents. Making them more accountable will ensure that meaningful learning takes place to create quality education.

\section{REFERENCE LIST}

Adesokan, R.O \& Makura A.H. (2020). Perceived effects of single-mother parenting on students' academic performance in selected high schools in Free State, South Africa. Proceedings of INTED2020 Conference, Valencia, Spain, 2-4 $4^{\text {th }}$ March 2020 (pp 1943-1947).

Chaka, A.G. (2006). Women's participation in school governing bodies. Unpublished Master's thesis. Faculty of Management. University of Witwatersrand, Johannesburg, South Africa. 
Chabaya, O., Rembe, S. \& Wadesango, N. (2009). The persistence of gender inequality in Zimbabwe: Factors that impede the advancement of women into leadership positions in primary schools. South African Journal of Education, 29(2).

Duku, N. \& Salami, I. A. (2017). The relevance of the school governance body to the effective decolonisation of education in South Africa. Perspectives in Education, 35(2), 112-125.

Denmark, F. L. and Diggory, C. (1966). "Sex differences in attitudes toward leaders' display of authoritarian behaviour." Psychological Reports) 18) 863-872.

Farrell C M \& J Law (1999). The accountability of school governing bodies. Educational Management \& Administration 27(1): 5-15.

Gamede, V. W. (2016). Constraints to effective governance by the parent component of the SGBs in Rural South Africa. International Journal of Educational Sciences, 13(2), 194-201.

Greif, A. (1994). Cultural beliefs and the organization of society: A historical and theoretical reflection on collectivist and individualist societies. Journal of political economy, 102(5), 912-950.

Heilman, M. E. (2001). Description and prescription: How gender stereotypes prevent women's ascent up the organizational ladder. Journal of social issues, 57(4), 657-674.

Heystek, J. (2011). School governing bodies in South African schools: under pressure to enhance democratization and improve quality. Educational management administration \& leadership, 39(4), 455-468.

Joubert, R. (2008). School governance in South Africa: Linking policy and praxis. ELMS, 97.

Karlsson, J. (2002). The role of democratic governing bodies in South African schools. Comparative education, 38(3), 327-336.

Kidder, D. L. (2002). The influence of gender on the performance of organizational citizenship behaviors. Journal of management, 28(5), 629-648.

Lewis, S. G., \& Naidoo, J. (2006). School governance and the pursuit of democratic participation: Lessons from South Africa. International journal of educational development, 26(4), 415-427.

Mabasa, T. and Themane, J. (2002) 'Stakeholder Participation in School Governance in South Africa', Perspectives in Education 20(3): 111-16.

Mafora, P. (2012). Shared decision-making in school governance: A case study of two Soweto secondary schools. International Journal of Learning, 18(6).

Marshall, C. (2004). Social justice challenges to educational administration: Introduction to a special issue. Educational Administration Quarterly, 40(1), 3-13.

Mcpherson, G. (2001) The status of governing bodies in the Education 2000 Plus schools 1998-2000 (Unpublished).

Mncube V.S. (2007) Social justice policy and parents understanding of their voice in school governing bodies in South Africa. Journal of Educational Administration and History 39(2): 129-43.

Mncube, V. (2008). Democratisation of education in South Africa: issues of social justice and the voice of learners? South African Journal of Education, 28(1), 77-90.

Mncube, V. (2010). Parental involvement in school activities in South Africa to the mutual benefit of the school and the community. Education as change, 14(2), 233-246.

Mncube, V. \& Du Plessis, P. (2011). Effective school governing bodies: parental involvement. Acta Academica, 43(3), 210-242.

Modisaotsile, B. M. (2012). The failing standard of basic education in South Africa. Policy brief, 72, 1-7.

Mpungose, J. E. \& Ngwenya, T. H. (2017). School leadership and accountability in managerialist times: Implications for South African public schools. Education as Change, 21(3), 1-16.

Popkewitz, T. \& Lindblad, S. (2000). Educational governance and social inclusion and exclusion: Some conceptual difficulties and problematics in policy and research1. Discourse: studies in the cultural politics of education, 21(1), 5-44. 
Prinsloo, I. J. (2005). How safe are South African schools?. South African journal of education, 25(1), 5-10.

Republic of South Africa (1996a) Constitution of South Africa (Pretoria, President's Office).

Republic of South Africa (1996b) South African Schools Act, No. 84 (Pretoria, Government Printer).

Sewell Jr, W. H. (2005). The concept (s) of culture. Practicing history: New directions in historical writing after the linguistic turn, 76-95.

Seleti, Y.N. \& Tihompho, G. (2014). Rural women subsistence farmers, indigenous knowledge systems and agricultural research in South Africa. Journal of Human Ecology 48(1), 33-41. https://doi.org/10.1080/09709274.2014.11906772

Stelter, N. Z. (2002). Gender differences in leadership: Current social issues and future organizational implications. Journal of Leadership Studies, 8(4), 88-99.

Verger, A. Novelli, M. \& Altinyelken, H. K. (2012). Global education policy and international development: An introductory framework. Global education policy and international development: New agendas, issues and policies, 3-32. 